USBAD Uluslararası Sosyal Bilimler Akademi Dergisi -

International Journal of Social Sciences Academy, YIl 3, Year

3, Sayı 7, Issue 7, Aralık 2021, December 2021

e Issn: 2687-2641

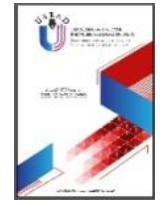

\title{
ATTİLA İLHAN ŞİİRLERİNDE EV VE AİLE BAĞLAMINDA MEKÂN
}

SPACE IN THE CONTEXT OF HOME AND FAMILY IN ATTİLA İLHAN POEMS

\section{Müslüm ENGİN}

Eğitimci, Ankara Sosyal Bilimler Üniversitesi, Türk Dili ve Edebiyatı, Kadın ve Aile Çalışmaları, Ankara/Türkiye.

Educator, Ankara Social Sciences University, Turkish Language and Literature, Woman and Family Studies,

Ankara/Turkey.

muslum.engin@student.asbu.edu.tr

ORCID ID: 0000-0002-6247-0791

\section{Makale bilgisi | Article Information}

DOI: $10.47994 /$ usbad. 1002928

Makale Türü / Article Type: Araştırma Makalesi / Research Article

Geliş Tarihi / Date Received: 30.09.2021

Kabul Tarihi / Date Accepted: 11.12.2021

Yayın Tarihi / Date Published: 20.12.2021

Yayın Sezonu / Pub Date Season: Aralık / December

Bu Makaleye Atıf İçin / To Cite This Article: Engin, M. (2021). Attila İlhan Şiirlerinde Ev ve Aile Bağlamında Mekân. USBAD Uluslararası Sosyal Bilimler Akademi Dergisi 3(7), 1777-1801.

Intihal: Bu makale intihal.net yazılımınca taranmıştır. İntihal tespit edilmemiştir. Plagiarism: This article has been scanned by intihal.net. No plagiarism detected.

\section{İletişim: Web: https://dergipark.org.tr/tr/pub/usbad mail: usbaddergi@gmail.com}


Öz: Ev, insanın dış dünyayı ilk defa gördüğü ve tanımaya başladığı mekândır. Ev, bununla birlikte insanın hayata dair deneyim, bilgi ve becerilerine ilk ve en kalıcı izler bırakan durağıdır. Şiirde evle ilgili imgelere yer vermek, aynı zamanda evrene doğru yolculuğun çıkış noktasını belirtmek demektir. Bu çalışmada Attila İlhan'ın şiirlerinde ev imgesinin ne şekilde tasarlandığı analiz edilmiştir. Attila İlhan, şiirlerinde aşk, romantizm ve bireysel duyguların yanı sıra toplumsal duyarılıı̆̆ı ön plana çıkarır. Şiirlerde tasarladığı mekânlarda, insanların yaşam koşullarına, beklenti, çaresizlik ve yalnızıklarına, kır ve kentteki ev tiplerine ve bu evlerde yaşayan insanların dünyasına yolculuk yapmaktadır. Şiirde ev imgesinin yorumlanmasında; Gaston Bachelard, Mehmet Narlı ve Nurullah Çetin'in şiir çözümlemesi ilgili yöntemlerinden yararlanılmıştır.

Anahtar Kelimler: Attila İlhan, Ev, Ev İmgesi, Ev ve Şiir, Şiir İncelemesi

Abstract: Home is the place where people see the outside world for the first time and get to know them. However, home is the first and most permanent stop of a person that leaves a trace on his experience, knowledge and skills about life. To include images about the house in the poem also means to indicate the starting point of the journey to wards the universe. In this study, how the house image is designed in Attila İlhan's poems was analyzed. Attila İlhan highlights social sensitivity in addition to love, romance and individual feelings in his poems. In the spaces he designed in his poems, he travels to the living conditions, expectations, desperation and loneliness of people, the types of houses in the countryside and the city, and the world of the people living in these houses. In interpreting the image of home in poetry; The methods of Gaston Bachelard, Mehmet Narlı and Nurullah Çetin about analyzing poetry were used.

Key Words: Attila İlhan, House, Image of House, House and Poetry, Poetry Analysis

\section{GİRIŞ}

Kurmacaya dayalı tahkiyeli metinler ile coşkuya dayalı şiirlerin insanın yaşamından hareket etmesi, onları bir yere ve mekâna bağımlı kılmaktadır. Yer; olayın ya da duygunun geliştiği, hayale ve estetiğe yansıyan hareket noktasını teşkil etmektedir. İnsanın nereden geldiği, ne yaptığı, niçin var olduğu ve ölümün gizemli sırları en eski çağlardan beri tartışılagelen bir konudur. Ancak insanın var oluşunun fiziksel ve ruhsal bir yer işgal ettiği bilinen bir gerçekliktir. Sanat ve edebiyat eserleri de insanla ilgili oldukları ölçüde, insanın yeri ile de ilgili olmuşlardır. İnsanın yerde (dünyada) var olmaya başlamasının dinsel ya da bilimsel pek çok farklı teoriye dayanan açıklamaları olmakla birlikte; tabiatta yaşamını sürdürmesinin fiziksel ihtiyaçları karşılayabilme gücüyle koşut olduğu, tüm çağlarda değişmeyen bir gerçek olarak iddiasını sürdürmeye devam ettirmektedir. 
Bu bağlamda barınma, insanın temel fiziksel gereksinimlerinden biri olarak öne çıkmaktadır. İnsanlar bir barınakta yakınlaşarak toplumların en küçük yapı birimi olan aileleri oluşturmuşlardır. Tarihsel ve kültürel birikimler aile kavramını, onunla aynı anlamda kullanılan "ev" kavramıyla bütünleştirmiştir. Ev, insanların fert ya da aile olarak yaşamını sürdürdüğü yer, barınak, konut, hane olarak tanımlanır. Evin kavramsal anlamı biraz daha genişlemeye uğrayarak, sadece aileyi değil; bir yurdu, milleti ya da vatanı da karşılayabilmektedir. Aynı zamanda gün içinde pek çok defa kullanılan; "evine bağlı adam", "eve dönüş yolculuğu", "evinize dönün burada istenmiyorsunuz" gibi deyim ve ifadeler ev mekânının pek çok deneyimle özdeşleştirildiği anlamını kuvvetlendirmektedir (Canatan, 2018: 56).

İnsanın barındığı yer olan ev, toplumsal ve kültürel değişimlere göre nesilden nesile farklı şekiller almıştır. İnsanoğlunun evi şekillendirme eyleminin psikanalitik bir alt yapısı olduğunu öne süren Nesli K. Bilen, ana rahmindeki belirsiz durumun insanların genetik mirası olan ev anlayışını belirlediğini vurgulamıştır. Ana rahminde ve doğduktan sonra anne kucağında korkunç bir zayıflık ortamında bulunan bebeğin, tabiata karşı yok olma ve dağılma korkularıyla daha güçlü addettiği babaya sığınarak baş edebildiğini öne sürmüştür. İnsanın cennetten sonra düştüğü ilk evi ana rahmi, ikinci evi dünya olmuştur. Bu nedenle insan, ilk evi olan ana rahminde neler hissetmişse dünyadaki yeni evlerini de ona göre inşa edecektir (Keskinöz Bilen, 2018: 84-86).

Evin şekillenmesiyle ilgili bu açıklamadan toplumsal değişim ve deneyimlere farklı yaklaşımlar getirildiği gibi, insanın ev eksenli bir hayat sürdüğü de anlaşılmaktadır. İnsan önce evin şekline göre tutum sergilerken sonra kendi evlerini tasarlar. Tasarlama kültürel etkilenme şeklinde de gerçekleşebilir. Ancak evin kendisi de kültürü gelecek nesillere taşır. Bu yönüyle bir mekân olarak ev, tarihi öneme sahip bir nesne görevi üstlenir. Tarihi bilinmeyen toplumlar, evleri olmayan, evlerinden herhangi bir kalıntıya rastlanılmayan toplumlardır (Narlı, 2004: 26).

Nurdan Gürbilek'e göre ise, insan daha çocukluğundan kendini şekillendiren bu evin kalıplarını kırmak için çaba göstermektedir. "Bir zaman gelir, onun için ev olmaktan çıkar ev. Ne erken çocuklukta olduğu gibi keşfedilecek bir dıştır artık, ne de dış dünyaya karşı sığınılacak bir iç. Tam olarak ne zaman yaşarız bunu: Evin dışarıya karşı bir sığınak olduğu kadar bir engel de olduğunu fark ettiğimiz an mı? Evin geçici, ana babamızın güçsüz, ölümlü olduğunu sezdiğimiz an mı? Yoksa evin bize bir iç dünya bağışlarken aynı zamanda büyük bir iç sıkıntısı da verdiğini, bir iç dünyası olmanın bedelinin bu iç sıkıntısı olduğunu fark ettiğimiz an mı?" 
(Gürbilek, 2014: 63). Burada insanın kendi iç dünyasının baskısı ile kendinden kaçmakta olması, fiziksel olarak mekâna yani eve bağlanmıştır. Diğer bir deyişle birey, ruhsal olanın fiziksel olana baskısını hissetmektedir. Kendisine sürekli olarak tabiata karşı güç kazandıracak, ev merkezinden dışarıya doğru açılan daha güçlü bir mekâna ulaşma hissini yaşamaktadır.

Diğer yandan kurulan her yeni mekânın içinde düşsel anlamda yaşanılan ilk evin izlerine rastlanılmaktadır. Yeni evlerde düşünceler, derinleştikçe ev kadar dağınık ancak yine ev kadar sistemli bir bütün olan anıların etrafında kümelenirler. Belleğin ve imgelerin iç içe geçerek bir anı düzeni oluşturduğu görülür. Böylelikle yaşanılan evlere ait düşler birbiri içine girerek, hayal gücünün de yardımıyla geçmiş günlerin değerlerini korur. Her yeni ev önceki evlerin deneyimlerine, oradan da çocukluğa kadar, çocukluğunun ilk evinin yansımalarına kadar götürür insanı. Evle ilgili anılar dış dünyadaki diğer mekânlardan elde edilen anılardan farklıdır ve insan onları yaşayıp hatırladıkça mutlu olur. Bu mekânsal imgelerin yarattığı düş gücü, heyecan ve imgelem zenginliği şiirsel olmakla birlikte, ruhlarda şiire yönelik bir eğilim oluşturur. Çünkü insan anılarındaki mekâna yani eve sözcüklerden çok şiirle dokunabilir, şiirle ulaşabilir. Buradaki sanatsal düşünce yaratma eylemi, diğer düşünce ve deneyimler kadar güçlü bir deneyimi ifade etmektedir (Bachelard, 1996: 33-34). Öyleyse şiirsel imgelemin kaynağı bir bakıma insanın yaşam tecrübelerinin de kaynağı olan ev ve eve dair anılar dünyasıdır. Evde aileyle acı ve tatlı yaşanılanlar, geçmişe ait deneyimler, tecrübeler, hayaller, beklentiler ve mutsuzluklar şiirin ifadesinde kendini göstermektedir.

Eve geri dönmek, iskân etmenin bir özelliğidir ve bir yönüyle de aşk duygusuna dayanır. Ev mekânı çevredeki tehditlere karşı güvenlik ve rahatlık duygusunu karşılamanın yanı sıra, unutulan, bilinçli ya da bilinçsiz tüm anıların ışığında, salt sevgiden daha farklı ve "romantik" karşılığı olan bir aşkı da karşılamaktadır. Şu hâlde şiirsel imgelemde eve dönüşü mümkün ve zorunlu kılan durumlardan biri de aşktır (Saei, 2019: 40-43).

Mehmet Narlı'ya (2014: 32) göre "mekânların dinsel, sosyal, kültürel, sanatsal hatta siyasal kimlikleri vardır ve bu kimliklerin imgesel ve simgesel içerikleri onlarla iletişimde bulunan insanların kimliklerinin oluşmasında önemli etkilere sahiptirler." Gün içinde yaşanan pek çok olay vardır. Bireysel ya da toplu olarak yaşanan tüm bu yaşantılar, insanın hayal gücü ile karşııklı bir etkileşim alanı oluşturmaktadır. "Bu yaşantıların yansımaları, mekânların hafızalarında durmakta ya da bu zaman ve mekânlar, bilinçli, bilinçsiz hafızanın arketipleri olarak yaşamaktadırlar." Duygular ve düş dünyası şiir olarak dile geldiğinde mekâna özgü bu 
kuvvetli yansımaların diğer tüm etkenlerden daha güçlü olarak şiirin doğasına nüfuz ettiği aşikârdır. Dolayısıyla "mekânların, insanlar; insanların, mekânlar üzerindeki izlerini, edebiyat eserlerinde aramadan yapılan her çözümleme eksik kalacaktır."

Edebiyat eserlerindeki evlerin izlerini konu edinen bu çalışmanın amacı, Attila İlhan'ın şiirlerindeki imgeleri "ev, ev yaşamı, aile, insan ve toplum" temaları bağlamında tespit etmektir. Toplumsal insancıllığı, "bıçkın delikanlı" duruşu ile bütün sanat yaşamı boyunca savunan İlhan'ın şiirlerinde, ev ve ev yaşantısına, aileye ne şekilde yer verdiği, hangi duygularla nasıl anlamlar yüklediği, analiz edilmeye çalışılmıştır.

Araştırmada, Attila İlhan şiirlerinde değişik mekân tasavvurlarının şiirlere ne şekilde yansıdığı soru olarak belirlenmiştir. Bu soruya bağlı olarak; Attila İlhan şiirlerinde değişik mekânlara örnek vermiş midir? Şiirlerdeki mekân örnekleri şairin yaşamından ya da düş dünyasından izler taşır mı? Şiirlerdeki ev mekânı, aile teması ile birlikte işlenmiş midir? vb. sorular araştırmanın alt sorularını teşkil etmektedir.

Uzun soluklu sanat hayatı boyunca pek çok farklı döneme ve olaya şahit olmuş, pek çok farklı alanda eserler kaleme almış, şiir konusunda yeniliklere de öncülük etmiş olan Attila İlhan'ın şiirleri; Cumhuriyet'in kuruluş ve mücadele felsefesi, sevgi, aşk ve toplumsal gerçeklerle idealize edilmiş zengin bir içeriğe sahiptir. Attila İlhan şiir için: "Şiir yalnız bilgiyle yazılmaz, duyguyla yazılır; bilginin duyguya duygunun imgeye dönüştürülmesi de şairin asıl işidir, yani zanaatı. İmgeleştirme süreci ve sistemi özgün olmayan şairin, etkileyici olabileceğine hiç inanmadım" demiştir (Ertop, 2005: 23). Bu bakımdan İlhan'ın şiirleri sanatsal edim açısından güçlü addedilerek mekânsal incelemeye tabi tutulmaya değer görülmüştür.

Bu çalışmada yöntem olarak nitel araştırma yöntemlerinden biri olan doküman analizi yöntemi kullanılmıştır. Doküman analizi yöntemi görüşme ve gözlem tekniğinin olanaklı olmadığı durumlarda, araştırmacılara belirli bir alanda yapılmış çalışmalardan yararlanarak bilgiye ulaşma olanağı sağlar. Genel olarak sosyal bilimcilerin yani tarihçiler, antropologlar, dilbilimciler, sosyolog ve psikologların bu araştırma yöntemini bir bilgi kaynağı olarak kullandığı bilinmektedir. Önceden yapılmış çalışmalar, uzun süreli bir zamana yayılmış analizler, düşük maliyetli ve zamanı tasarruflu kullanma becerisi ile örneklem çerçevesinde hareket etme kolaylığı, bu nitel analiz yöntemini araştırmacı için yararlı kılmaktadır (Yıldırım ve Şimşek, 2016: 189-192). 
Bu kapsamda şairin, Ayrılık Sevdaya Dâhil, Bela Çiçeği, Ben Sana Mecburum, Elde Var Hüzün, Kimi Sevsem Sensin, Sisler Bulvarı, Yasak Sevişmek şiir kitapları incelenmiş, ev mekânı bağlamında aile ve toplum eksenli şiirlerinden örnekler verilerek, analiz edilmişlerdir. Şairin şiirlerinde çok farklı konuların izlerinin sürülebileceği düşünüldüğünde, ev özelinde mekân sınırlamasına yönelik bir çalışmanın farklı bir bakış açısı getirmek açısından olanaklı olduğu düşünülmüştür. Çözümlemelerde Bachelard ve Narlı'nın şiir ve mekâna yönelik yaklaşımları ile Nurullah Çetin'in Şiir Çözümleme Yöntemi eserinden faydalanılmıştır.

\section{Attila İlhan Şiiri}

Cumhuriyet döneminde şiirde imgelerin yeri ve şiirin dili üzerine derin tartışmalar yapılmıştır. Kimi sanat ekolleri şiirde şairane söyleyişe ve abartılı süslemeye yer verilmemesi gerektiğini öne sürmüşlerdir. Onlara göre şiirde imge yalnızca duygu ve düşünceleri daha rahat ve anlaşılır ifade etmenin bir aracı olmalıdır. Bunun tam aksini düşünen imgeci sanatçılara göre ise imge, şiirin kendisi ve amacıdır. Şiir duygu ve düşünceleri ancak imgeler yolu ile kurgulayabilen sanatsal bir üründür (Geçgel, 2007). Bu genel kavramsallaştırmaya Cumhuriyet döneminde ortaya çıkan iki ana akım şiir hareketi örnek gösterilebilir. Bunlardan biri, şiiri ağır dil ve süslü söyleyişten uzaklaştırıp günlük konuşma dilinin ve yaşantının olağan seyrine ayak uyduran bir yapıya dönüştüren "Garipçiler"dir. Bu yaklaşıma tepki olarak "İkinci Yeni" anlayışı ortaya çıkmıştır. Bu akımın içinde sayılan şairlere göre ise şiir tamamen imgelerle oluşan bütünsel bir yapıdır. Günlük yaşamı ve sıradan olayları değil, insanın imge dünyasının estetik biçimlerini yansıtmalıdır. Attila İlhan'ın şiiri anlayışı ise her iki gruptan ayrı bir yere konulmalıdır. İlhan hem Garip hareketine hem de İkinci Yeni'ye karşı gelerek, sosyal realizmi özgürlükçü bir platform olan Mavi Hareketi dâhilinde savunmaya çalışmıştır. Ona göre Garip Hareketi ve İkinci Yeni'nin şiir anlayışları toplumu yansıtmaktan uzaktır. Bu akımlar daha çok kendi dönemlerindeki iktidarın güdümünde olan bir şiir anlayışı geliştirmişlerdir (Ayten ve Koray, 2018: 114; Emiroğlu, 2019: 217).

Attila İlhan, şiirlerinde toplumcu gerçekçi hassasiyeti öne çıkarmanın yanında ölüm, aşk, korku, cinsellik ve şehvet gibi insanın doğasından kaynaklanan konulara da ağırlık vermiştir. Ona göre "sanatçının doğa/insan hatta evren/insan karşıtlığının, bilincine yansıyan çelişkileri ifade etmesi, gelecek kuşaklarca benimsenmesini hazırlayan yollardan biridir. Doğasal diyalektik sorunları, toplumsal diyalektik sorunlarından daha süreklidir. Evren durdukça varlık ve yokluk diyalektiği işlenecektir" 
(Çetin, 2019: 66; İlhan, 2018c: 121). Bu bakımdan en genel ifadeyle Attila İlhan'ın şiir poetikası, bir yandan "toplumcu gerçekçilik"* kavramının yeniden teorileştirilmesi, diğer yandan estetiğin şiire mutlaka yansıtılması ilkelerine dayanmaktadır. Estetik olmadan hiçbir sanat eseri anlaşılamaz, İlhan'ın daha ilk şiirinden itibaren toplumcu düşünce ile estetiği kaynaştırması ona büyük avantaj sağlamıştır (Celal, 2019: 110).

\section{Ev, Aile ve Çocukluğa Özlem}

Attila İlhan'ın şiirlerinde en çok dile getirilen özlem duygusu aileye ve çocukluğa duyulan özlem şeklinde kendini göstermektedir. İnsan anne ve babasından, kardeşlerinden, diğer aile bireylerinden uzun süre ayrı kaldı mı onlara hasret duyar. Aynı şekilde içinde yaşanılan zamanın mutsuzluğu, geçmişte önemli ve değerli görülen anlara, güzelliklere ve mutluluklara dönmeye neden olur. Şair şiirinde geçmişi hatırlar, anne ve baba şefkatini özler, çocukluğa dönmeyi ister, çocukluğun mutluluk anlarını içinde yaşanılan zamanla kıyaslar (Çetin, 2019: 63):

"olmuyor neyleyim

olmuyor velinimetim efendim

olmuyor yirminci asırda

tarz-ı kadim üzre gazeller söylemek,

$\cdots$

sen benim velinimetim efendim

ben senin hayr-ul-halef

sen vakt-i zamanında

uyan derdin uyan ey mest-i habinaz

uyan artık uyan

bense uyandım hab-i gafletten

uyan derim uyan ey esirler dünyas!!"

(Tarz-ı Kadim, Sisler Bulvarı, 97)

Babanın şairin düş ve fikir dünyasını etkileyen ağırbaşlı konumu ile gece yatağında uyurken merhamet ve sevgiyle saçlarını okşaması iç içe geçmiştir. İnsan neye muhtaçsa ya da en çok neyin tesirinde kaldıysa onun hülyası ile meşgul olmaktadır. Bu şiirde de, bir yanda babanın öğüt veren otoriter kimliği diğer yanda şefkatli yönü bir arada dile getirilmiştir.

Göçebe ve kırsal kültürde, halk türkülerinde evle ilgili deyimlere sıkça rastlanmaktadır. Evler, evlerin önündeki bitkiler, ev içinde yapılan işlere

\footnotetext{
* Gerçek ve gerçeğin toplumsal realiteler gözetilerek yeniden eleştirilmesine dayalı sanat ve edebiyat akımı. Gerçeği eleştirirken yeni yollar ve çözüm önerileri sunması ile bilinir. Rusya'daki 1917 Devrimi'nden sonra belirginleşerek büyük ölçüde Marksizm ideolojisine dayanmıştır. "Toplumcu gerçekçilik, Sosyal Gerçekçilik, Sosyalist Gerçekçilik, Marksist Gerçekçilik" gibi genellikle aynı anlayışı ifade eden değişik adlandırılmaları söz konusudur (Çetişli, 2019: 95).
} 
ait pratik deneyimler tabiatla uyum içinde işlenirler. Gerçek ve mecazlı tüm söyleyişler, istek ve beklentilerle uyum halindedir ve genellikle sevgi temel değerine bağlıdır (Narlı, 2014: 63). Attila İlhan'ın da bu şekilde tasarlamış olduğu evlerde sevginin, bakımın ve koruyuculuğun ilk kaynağı annedir:

"bu döşeği sen mi serdin elin dert görmesin ana ana uyuyacağım ninni çağır danalar girsin bostana çetin bir yörük kızı hoyrat murat dağı'ndan bir papatya getirsin bir gelincik getirsin elimden tutsun beni metristepe'ye götürsün $\cdots$

bu höşmerimi sen mi ettin eline sağlık ana ana lokma dökelim aşure kaynatalım hayır dağıtalım hayır ali osman dayıma ördügüun bu çorabı sağlıcakla giyiyorsam tuzladığın bu ayranı afiyetle içiyorsam tuttuğun bu yoğurdu yoğurduğun bu ekmeği kaynattığın bu bulguru çalakaşık yiyorsam etime ve sütüme ineğimin ıslıklı memelerine kabıma kaçağıma toprağıma bu benim diyebiliyorsam ..."

(Hayır, Sisler Bulvarı, 140)

Annenin şairin düş dünyasında anlam bulan, ev ve aile içindeki birliktelik ve pratik deneyimlerin her biriyle doğrudan ilgili olduğu anlaşılmaktadır. Sedanur Alınmış (2019: 27)'ye göre, bireyin çocukluğu anne ile bütünleşir ve anne bir nevi çocukluğun kalesidir. Anneyi kaybetmekle, deyim yerindeyse kale yıkılır, yetişkinliğe hızlı ve zorunlu ve aynı zamanda hüzünlü bir adım atılmış olur.

Anne çocukluk ile özdeş olduğu gibi, çocukluğun geçtiği her mekânla yaşanılan her anla özdeşleşen en önemli figür konumundadır:

"...

rüzgârda kıvılcımlar

"...valde sizlere ömür

beykoz'a yolculuk..."

"...iyileşeceğinden

ne kadar umutluyduk

geçen ziyaretimizde

ud çalmıştı bize

...nasıl da mutluyduk

dün gece 
sabaha karşı

işte ansızın..."

"...insan annesi ölünce anlar

içindeki çocuğun

hiç ölmeyeceğini

aklına geldikçe kahrolur

bunu anlamakta

neden

bu kadar geciktiğini..."

(IV. Beykoz'a Yolculuk, Kimi Sevsem Sensin, 76)

Anneyi kaybetmek çocukluğu unutmak, çocukluğun geride kalması değil; bilakis annenin düşü ile birlikte sürekli geçmişte yaşamayı ifade etmektedir. Anne ve baba dışında romantik aşk duyguları da çocukluğun mekânları ile özdeşleşmektedir. Çocukluğun mekânına geri dönüş, merhamet isteği dışında romantik birtakım duygulara da dayanmaktadır:

"istanbul ve sen / neydi o bir zamanlar sanki gençliğime doğru yaşlanıyordum çengelköy'de yaz unutulmaz erguvanlar hangi yanıma dönsem seni bulurdum içimdeki lambanın kırıldığı anlar istanbul ve sen / sırılsıklam yaşananlar yanardöner bir ayna yeniden ruhum çengelköy'de yaz unutulmaz erguvanlar gözlerinin sisinde sevdalı bir yolcuyum hayal meyal gemiler dumanlı ilkbahar istanbul ve sen / ikinizden kalanlar tekrar tekrar ısrarla yaşayıp durduğum çengelköy'de yaz unutulmaz erguvanlar rüya mıdır gerçek mi kendi kendime sorduğum istanbul ve sen / neydi o bir zamanlar"

(Kimi Sevsem Sensin, Neydi O Bir Zamanlar, 31)

Romantik duygu, gençliğin ya da ilk çocukluğun sevinçli bahar manzaraları yerine, ayrılıktan ve hasretten kaynaklanan hüzünlü sonbahar mevsimiyle ilgili çağrışım yapmaktadır (Çetin, 2019: 68). Attila İlhan'da aşk duygusu sosyal meselenin dışına taşmaz. Aşkı hatırlamak, onu en zor zamanda hayata bağlayan güçtür. Yaşanılan acıdan sıyrılmak, içinde bulunan zaman ve mekânı unutup bir teselli bulmak, yaşanılan eski mekânlardaki tatlı aşk hatırlarını anmakla mümkün olur (Yılmaz, 2018: 362). 
Aile evinde geçirilen çocukluğun ilk yılları şairin dünyasında bahar mevsimi olarak imgeleşmiştir. Hatta bu evde yaşanılan güzel anlar ve nesneler ile olan ilişkilerin yansımaları da şiirlerde kendini göstermektedir:

$"$ "..

mükerrer bir yanılgı mıdır her sabah

(o müz'iç yeni bir hayata başlamak duygusu)

güller vazoda buruşmuş

sisler mahzunluğunu dağıtıyor

kahvaltı sofrası çoktan hazır

harem'de balkona kurulmuş

gümüş bir fısıltıdır semaver

kızarmış ekmek kokusu

lacivert karanlığı

böğürtlen reçelinin

..."

(Nakilan-ı Asar, Elde Var Hüzün, 86)

Tatı bir uykudan uyanırken hazırlanmış olan kahvaltının ev içindeki kokusu ve her sabah gerçekleşen bu eylemin zihinlerde bıraktığı nesnelere dair izler, huzurla ifade edilebilecek bir ev yaşantısının mirası olarak görülmektedir. Ev içindeki nesnelerin hülyası insanı her zaman hoş hatırlanan hatıralara götürmez. Bazen bu nesneler hayal kırıklıklarını, zamanın hızla akıp geçmesini, yalnızlığı ve hüznü de karşılayabilir. İmgeler nesnelerin etrafında birleşerek her biri şairin düş dünyasında geçmişin salonlarına açılan birer pencereye dönüşürler. Mekânın bir işlevi de, geçmişte yaşanılan zamanı durdurmuş olmasıdır. Belleğin dekorunda kişiler öne çıkan özellikleri ile korunur. İnsan zamanla kendi yerine, varlığının mekân içine hapsedilmesiyle belirginleşen hallerini tanır (Bachelard, 1996: 36). Attila İlhan'ın dizelerinde de zamanla birlikte mekânlara hapsolmuş durumlar söz konusudur:

"zaman olmuştur ki

dumanlı havuzlarda soğuk nilüferler

bulutlara savrulmuş ateş kuşları

korkulu bir hicranı söyler

zaman olmuştur ki

dalgınlıkları hisarbuselik kızların

bildik şarkıları birden unutuşları

aynalarda solan gün

bilinmez hangi uğultulu

ahval-i perişanı söyler

zaman olmuştur ki

loş salonların heyula büfelerinde 
o kristal fanuslu yorgun saat

fena halde durmuş görünse de

başka bir boyutta başka bir zamanı söyler

zaman olmuştur ki

falcının avucunda tuttuğu sihirli küre

aslında yaşanmamış belki hiç yaşanmayacak

ancak ne kadar renkli

ne kadar yanardöner bir ömr-i zerefşani söyler ".."

(Söyler, Ayrılık Sevdaya Dâhil, 43)

Şiirde geçen "Aynalı loş salonlarda kristal fanuslu saatler" ya durmuş ya da yanlış zamanı göstermekteler. Zaman şairin zihninde eski bir hatıraya takılı kalmış. Kalabalıklar içinde daha mutlu bir ailenin bir arada yaşadığı başka bir zaman dilimini düşlemektedir.

\section{Evde Yalnızlık ve Eve Sığınma}

Ev hem kalabalık halde yaşanan hem de yalnız kalınan, kendine ait özel bir dünyanın yaratıldığı yerdir. Her bireyin yaşadığı evde kendine özgü özel bir alanının olmasını istemesi en doğal hakkıdır. "Geçmişteki yalnızlıklarımızın tüm mekânları, içinde yalnızlıktan acı çektiğimiz, yalnızığın tadını çıkardığımız, yalnızlığı aradığımız, yalnızlıkla uzlaştığımız mekânlar içimizde silinmez olarak kalmıştır. İnsan onları özellikle silmek istemez. Yalnızlığın bu mekânlarının kurucu özellikte olduğunu içgüdüsel olarak bilir" (Bachelard, 1996: 37). Şu hâlde yalnızlık, mekânla bütünleşerek bir özgür olma durumu olduğu gibi, bir acı çekme halinin de karşılığıdır:

"yalnızlık hızla alçalan bulutlar karanlık bir ağırlık

hava ağır toprak ağır yaprak ağır

su tozları yağıyor üstümüze

özgürlügüumüz yoksa yalnızlığımız mıdır

eflatuna çalar puslu lacivert bir sis kuşattı ormanı

karanlık çöktü denize

yalnızlık çakmak taşı gibi sert elmas gibi keskin

ne yanına dönsen bir yerin kesilir fena kan kaybedersin

kapını bir çalan olmadı mı hele elini bir tutan

bilekleri bembeyaz kuğu boynu parmakları uzun ve ince

sımsıcak bakışları suç ortağı kaçamak gülüşleri gizlice

yalnızların en büyük sorunu tek başına özgürlük ne işe yarayacak

bir türlü çözemedikleri bu ölü bir gezegenin soğuk tenhalığına benzemesin diye özgürlük mutlaka paylaşılacak suç ortağı bir sevgiliyle

sanmıştık ki ikimiz yeryüzünde ancak birbirimiz için varız 


\section{Müslüm Engin}

ikimiz sanmıştık ki tek kişilik bir yalnızlığa bile rahatça sığarız hiç yanılmamışız her an düşüp düşüp kristal bir bardak gibi tuz parça kırılsak da hala içimizde o yanardağ ağzı hala kıpkızıl gülümseyen sanki ateşten bir tebessüm zehir zemberek" (Ayrılık Sevdaya Dâhil 4. 79-80)

"kapıyı açık bırak

hiç kimse görmese de

belki birisi gelir

elsiz ayaksiz

varla yok arası

hanidir bekliyorum"

(Kimi, Ayrılık Sevdaya Dâhil, 108)

Bu dizeler evde, çok hazin bir yalnızlığın yaşandığı, kapıların açık bırakılarak gelecek bir kişinin yolunun gözlendiği anların ifadesi olmuştur. Ayrıca şairin bu satırlarda yalnızlığın tahammül edilemez acısını ifade etmek için kullandığı "yanardağ ağzı" imgesi, Bachelard'ın yaşama içgüdüsü ile ölüm içgüdüsünün bir arada olduğunu ifade ettiği Novalis Karmaşası ile açıklanabilir. Bachelard (1995: 21)'e göre "Ateş zamanı değiştirmek, sarsmak, bütün hayatın sonuna, öbür dünyaya götürmek arzusunu telkin eder. O zaman hayal hakikaten sarıcı ve heyecan verici olur... küçüğü büyüğe, ocağı yanardağa... bağlar. Yok olmak (yanan için) değişmekten öte bir şey, yenilenmektir." Yalnızlığın verdiği tahammül edilemez acıdan kurtulmanın bir yolu olan kendini yok etmek sonucu bu karmaşa ile açıklanabilir. Kimi zaman da yalnızlık bir evde ömür boyu katlanılan bir durum olmaktadır:

"hayal kuşlara üretir marifetli tığından

esrarlı sarmaşıklar yaprakları tırtıllı

bir rüya çıkarıyor yaşadığından

yoksa yaşlı mıdır sanıldığından

tığ ucunda bir ömür nasıl çalkantılı

yakınlığı duyulmamış hastalığından

o yalıda eskiyor camları martılı

akasyalar büyür yağmurlarından

dantel gibi zarif ışık kırpıntııı"

(Tığ Örgüsü Yaşlı Baladı, Ayrılık Sevdaya Dâhil, 19)

Bu dizelerde, tek başına ve başka insanların ilgisizliğiyle karşı karşıya olan bir yalnızlıktan söz edilmektedir. Toplum tarafından dışlanan, ruhsal, düşüncel ve duygusal bir sosyal paylaşım alanı bulamayan insanlar yalnız 
insanlardır. Sosyal bir varlık olan insan bu duruma katlanamaz ve yalnızığın bu türü insana acı verir (Çetin, 2019: 77):

"zeynep beni bekle / gece ağaçlarına

yağmur çiseliyorum / cam tozu su beyazı

yalnızlığını mutlaka değiştireceğim

bir yaprak halinde süzülüp saçlarına

...

geceleyin ışıkları söndürdügün zaman

benim şiir kitaplarından sızan aydınlık

elinde uyuyakaldığın heyecanlı roman

pancurların çarpıldığı lodos geceleri

rüzgârın değil benim / pencerendeki ıslık

her akşam koridordaki ayak sesleri

yanlış çaldığını zannettiğin telefon

zeynep beni bekle mutlaka geleceğim

hem bu ne ilk ayrılığımız ne de son

(Zeynep Beni Bekle, Elde Var Hüzün, 28)

Yalnızlığın diğer bir hali de beklemektir. İnsan bu dizelerde dile getirildiği gibi, bazen bir sevgiliyi ömür boyu umutla bekler. Bazen aileden birini, bir komşuyu, bir haberi, ıstırapla geçen yorgunluk dolu bir hastalık gecesinden sonra sabah olmasını, esaretteyken özgürlüğüne kavuşmayı, mesai saatini bitirip de huzurla dinleneceği evine dönmeyi, hâsılı insan hayatının her anında mütemadiyen bir şeyleri beklemektedir. Bu dizelerdeki Zeynep gibi yalnızlığın kendisini bile beklemektedir.

Kalabalıklar içindeki hissedilen yalnızlık duygusu ise ya kimsesizlikten kaynaklanır ya da fikir ve felsefi düşünce açısından başka insanlarla uyuşamayan kişilerin yaşadığı özel bir yalnızlık durumunu ifade eder (Çetin, 2019: 77).

"bizi tanıştırmadılar evet yalnızım

eş dost arasında büsbütün yalnız

aslında kararsızım dilim dolaşıyor

gözleriniz olmasa konuşamayacaktım

hep böyle cana yakın mı bakarsınız

hafif koyu kestane az yeşile çalıyor"

(3. Elde Var Hüzün, 28)

Diğer yandan ev, yalnız başına ya da aileyle yaşam sürdürülen bir yer olduğu gibi; tehlike zamanlarında ev halkına, yolcuya, misafire sığınak sunmakta, onları güvenle örtmektedir:

"öteki kapımdan gel bunu açamazsın

eski gözlerinle gel öldürmek vakti gel 
hem tetik bulun ardında biri olmasın hanidir ben bu evde saklanıyorum adımı değiştirdim başka bir adla yaşıyorum gece gündüz siyah gözlük kullanıyorum sabaha karşı gel eski gözlerinle gel ... artık hiç kimse beni yaşamıyor aşklarımı büyük kemanlarla çizdiler korkularım oldum bittim kimsesizdiler yalnız bir misra mıyım ıslanıyorum bir revolver romanımı tamamlıyor oyun bitti ışıklarımı söndürdüler

üzerime kilitleyip mühürlediler hem tetik bulun ardında biri olmasın"

(Yasak Sevişmek, Yasak Sevişmek, 46)

Kimsenin bulamayacağı, sığınılan yer olarak ev; dağ başlarında tekinsiz bir mağaradan ya da uçsuz bucaksız vadilerden bile güvenilir bir liman olmuştur. Bu satırlardan ev mekânının insanın tüm çaresizliklerinin ve acılarının da ne denli büyük bir tanığı olduğu ortaya çıkmaktadır. İnsanların yaşadıkları mutluluklara mukabil ne büyük acılara tanıklık ettiklerini duvarlardan öğrenmek mümkün değil belki; ancak evin dili olan bu dizelerden hissedilebilmektedir.

Evin şahitlik ettiği sürekli bir sıkıntı hali de geçim sıkıntısı ve yoksulluk olmaktadır. Atilla İlhan şiirlerinde "ekonomik zorluklar içinde yaşamını devam ettirmeye çalışan göçmen, kentin zengin ve orta kesimi içinde dış görünüşü ve yaşam tarzı ile kent içinde kentli olamayanların" sıkıntılarını da konu edinir (Yılmaz, 2018: 164). Yanı sıra Attila İlhan'ın şiirlerinde evdeki yalnızlık, kaçaklıkta eve sığınmak gibi yoksulluk temaları toplumsal yönü olan konularla birlikte vurgulanmaktadır:

"ben ne inim, ne cinim, ben bir garip ademim.

barakmuslu köyü'nden selâmsız oğlu bekir, yıkılası hanede sekiz boğaz avcuma bakar, ben kendimi toprak bilirim, toprak beni baba bilir, benim köyümde avrat bile toprak gibi sevilir. ben ne inim, ne cinim, ben bir garip ademim. nideyim bu mezarda babam yok, yalnız anam var, dedem yok bu mezarda, fukara ninem yatar. söyleyin dağlar-taşlar, ben selâmsız oğlu bekir, iki gözüm iki ateş parçası, iki taş parçası iki elim, yıkılası hanede sekiz boğaz avcuma bakar"

(Barakmuslu Mezarlığı, Sisler Bulvarı, 116) 
Kırsal kesimde geniş aile içinde yaşamak, evin ekonomik durumunu etkilediği gibi, karı koca arasındaki ilişkiler; anne, baba ve eşin konumlarını da belirlemektedir. Yoksulluk bir yandan da bir çeşit yalnızlığın ve kimsesizliğin ifadesi olmuştur.

Öte yandan yalnızlık korkusu, şairi sevgiliye duyulan aşkını abartılı bir şekilde ifade etmeye, hüznü dillendirmeye yöneltir (Çetin, 2019: 68):

"beni koyup koyup gitme, n'olursun

durduğun yerde dur

kendini martılarla bir tutma

senin kanatların yok

düşersin yorulursun

beni koyup koyup gitme, n'olursun

bir deniz kıyısında otur

gemiler sensiz gitsin bırak

herkes gibi yaşasana sen

işine gücüne baksana

evlenirsin, çocuğun olur

beni koyup koyup gitme, n'olursun"

(Ağustos Çıkmazı, Ben Sana Mecburum, 44)

Ayrılığın sonucu olan kara sevdaya dayanamamak, sevgiliden uzakta tümden çaresiz kalmaktansa onu evlenmiş, mutlu olmuş biri olarak görmeye şairi ikna etmektedir. Ayrıca burada şaire göre evlenmek, çoluk çocuğa karışmak herkes gibi olmak anlamına gelmektedir. Diğer bir deyişle şiirde aile yuvası, macera peşinden koşmak yerine, sükûnetin temin edildiği bir yerdir ve burada, bu yuvaya şiirsel bir davet söz konusu edilmektedir.

\section{Kentin Evleri, Otelleri ve Bekâr Odaları}

Ev yapıları Osmanlıdan Cumhuriyet'e kültürel birikimle zamanla değişime uğramış, değiş̧ik ev tipleri ortaya çıkmıştır. Şehir merkezlerinde ahşap ve kâgir malzemeden yapılan konaklar bunların en büyüğüdür. Türk insanının yaşam biçimi ve değerleri ile ilgili en kuvvetli hafızaya sahip olan evler bunlardır. Deniz kenarında ahşaptan yapılan yalılar ile genellikle gezinti ve mesire yerlerinde bahçe içlerinde yapılan köşkler diğer ev çeşitleridir (Narlı, 2014: 27). Bunların dışında hem toplumsal hafızayı hem de bireysel yaşantıları belirtmeleri bakımından köy evleri, kalabalık kentlerde bekâr odaları ve oteller, Attila İlhan şiirlerinde evin birbirinden farklı yaşantılar barındıran hallerini teşkil etmektedir:

$" . .$.

besbelli bu gece yıldızlar görünmeyecek

yağmur aralandı $m ı$ 
dumanlıboğazı'na geyikler gelirmiş

tahta gibi dağ köylüleri fırat'ın arkasından

bazı bazı türkmenler hiç umulmadık

uzun yeleli bal rengi atlarıla

yemeni yorganları ve yün yataklarıyla"

ve çıtırtılı ateşleriyle böcek böcek"

(Ya Bereket Deyip Islanıyoruz, Ben Sana Mecburum, 65)

Ovayla, vadiyle, bulut ve yıldızlarla alabildiğine iç içe olan göçmen Türkmenlerin evlerini sırtında taşıdığını dile getiren bu dizelerde, göçmenlerin tabiattan sesler eşliğinde yarı meskûn bir hayat sürdüğü dile getirilmiştir. Diğer yandan dağ köylerinde insanlar; göçebe hayattan kurtulup ev tutmak, geçimlerini sağlamak, hayata tutunmak için büyük bir mücadele vermektedirler:

"siz yukarı çiğli'den misiniz

o nasıl şey

demek gözleriniz ışık tutmuyor

ellerinizi bir sattınız bulamıyorsunuz

bu evleri böyle tutan siz misiniz

o nasıl şey

insan gözlerine inanamıyor

sofraya buyurun sofraya

belli yorgunsunuz

peynir kestim sucuk doğradım

günbalı erittim bakın ya

içinizi ısıtırsınız

su içersiniz

sofraya buyurun sofraya

buğday konuşacağı"

(Mustafa Kemal'in Sofrası, Ben Sana Mecburum, 77)

Ev tutmak ifadesinin kullanımasının nedeni; bir yeri yurt bellemek için, orada buğday ekip gece gündüz demeden çabalamak, emek sarf etmek, bir sofranın etrafında hep birlikte oturmak gerektiğini vurgulamaktır. Köy evinde yaşamak zorludur. Tabiatla mücadele etmek ve her gün yeniden başlayan, bitmez tükenmez işler halletmek insanı yıpratmakta, kendi bedenine bile yabancılaştırmaktadır.

Öte yandan merhametli insanlar başka insanların ve canlıların yaşadığı olumsuz durumlardan rahatsız olurlar. Şairler de fakir ya da herhangi bir konuda çaresiz insanların acıları karşısında sessiz kalamamaktadır. Şiirlerinde acı çeken insanların sıkıntılarını dile getirerek üstü örtülü de olsa onlara destek vermektedirler (Çetin, 2019: 64). Attila İlhan'ın şiirlerinde pek çok yerde bu merhametin, sosyal duyarlılığın izlerine rastlamak mümkündür: 
$"$

kibrit çaktım cevahir, yalazını yel aldı gitti

derecikviran köprüsünü bıldır sel aldı gitti

adın batsın sel, cevahir'i yaktın sel

iki baş düvesi ve yetmişlik anası hilâfsız boğuldular

ocağını söndürdün ocağına incir diktin sel"

(Derecikviran, Sisler Bulvarı, 135)

Bu dizelerde tabiatın karşısında çaresiz kalan insanın yaşadıkları "ocağına incir dikmek" deyimiyle ifade edilmiştir. Ocak (ev) insanların sevdikleriyle birlikte yaşadıkları mamur yerdir, onu yitirmek her şeyini yitirmekle eşdeğerdir. Tabiatın ortaya çıkardığı zorluklardan bir parça ırak olan evlerin içinde ise kendine has bir sükûnetin arkasında farklı sorunlar söz konusu edilmektedir:

"gül gibi

geçinip gidiyorlar işte

yeşil panjurlu evde

o iki kadın

ve çocuk

acaba

hangisine baba diyor"

(Yeşil Panjurlu Ev, Ayrılık Sevdaya Dâhil)

Kentlerde evde yaşayan kişi sayısı azalmış, kalabalık sofralar etrafında toplanan göçmen ailesi ya da köy yerindeki gibi geniş aileler giderek daralmıştır. Kent ailesinde aile ilişkilerinin giderek farklılaştığı, ebeveyn-çocuk ilişkilerinin yeni formlara büründüğü kimi dizelerden anlaşılmaktadır. Bununla birlikte kentlerde yaşanılan evler her zaman küçük, yeşil panjurlu evler gibi mütevazı olamamaktadır. Gösterişin, zenginliğin, konforun ya da daha rahat bir yaşamın sürüldüğü köşkler, kalabalık yalılar da, İlhan şiirlerinde sıkça yer bulmaktadır:

"dallarında kuş yağmuru

köşkün bahçesindeki

manolya ağacının

güneş yemyeşil damlıyor

kaygan yapraklarından

akşam üstüdür

ikisi de odasına çekilmiş

küçük hanım roman okuyor

büyük hanım kur'an"

(Akşamüstü, Ayrılık Sevdaya Dâhil, 100) 
Bachelard, bahçesinde içinde kuşların oturduğu ağaçların yer aldığı bir evin insan gözünde diğerlerine göre daha kıymetli olduğunu belirtmiştir. Çünkü içinde kuş bulunan ağaç bir yuvaya sahiptir. $O$ ağaçtan gelen sesler bir ev için çabalayan iş̧̧i kuşun emeğini yansıtmaktadır. Bu ses insanı rahatsız etmez, bilakis insana yaşamın anlamlı varlığının mesajını sunmaktadır (Bachelard, 1996: 118). Bu şiirde ise bahçesinde asude bir yaşamın temsilcisi kuş cıvıltılarıyla dolu ağaçların olduğu köşkte yaşayan insanların içinde yaşadıkları kültür zeminine göre büründükleri ev halleri betimlenmiştir. Köşkün dışındaki neşeli tabiat ve renk cümbüşünün evin içine yansımamış olması bir zıtlık olarak öne çıkmaktadır. Buradaki köşkteki bu sessizliğe mukabil; kalabalık ve ziyafetli eğlencelerle dolu yalılar, ev mekânının farklı bir boyutunu temsil etmektedir:

"kanlıca'da

Kadızade eşref'in yalısı

nedense bu yıl gözü yaşlı teşrinlerin

içi paslı kötümser

kafeslerin ardında yağmur şakırtısı

su dumanı savrulur ağaçlardan

her çakışında şimşeğin

maytap yeşili kediler

olmadık bir yerinde

tutuşur gecenin

her akşam böyle bir 'hünkar sofrası'

sieber 'paşa'nın 'müstesna' hareminde

zerde ve pilav

baklava ve börek

hilafsız adam boyunda ayaklı şamdanlar

telkâri gümüş

..."

(Şöyle Rivayet Ederler Kim, Elde Var Hüzün, 89)

İnsan zihninde iz bırakan, bahçesi, saçağı, sofası olan, gösterişli detaylarla dolu konak, köşk ve yalı kültürü, modern zamanlarda ortaya çıkan apartmanlaşma ve konutlaşma süreciyle özgünlüğünü yitirmiştir. Hepsi birbirinin benzeri bir planda yapılan, küçük ve iç mimariden genellikle yoksun olan daireler, tekdüzeliği temsil eden sınırlı bir özgünlüğe sahiptir (Narlı, 2014: 28). Köşklerde, konak ve yalılarda yaşanmış nostaljik anların, modern zamanlarda apartmanlarda yaşanılan hayata göre daha şiirsel bir estetikle dile getirilebildiği ve şiirlere daha fazla konu olmayı başardığı görülmektedir. 
Attila İlhan şiirlerinde sıklıkla öne çıkan mekânlar olarak bekâr odaları ve oteller de dikkat çekmektedir. Evin yaşattığı düzen ve mutluluk hissine karşılık, buralarda hep başıboşluk, amaçsızlık ve hüzün hâkimdir:

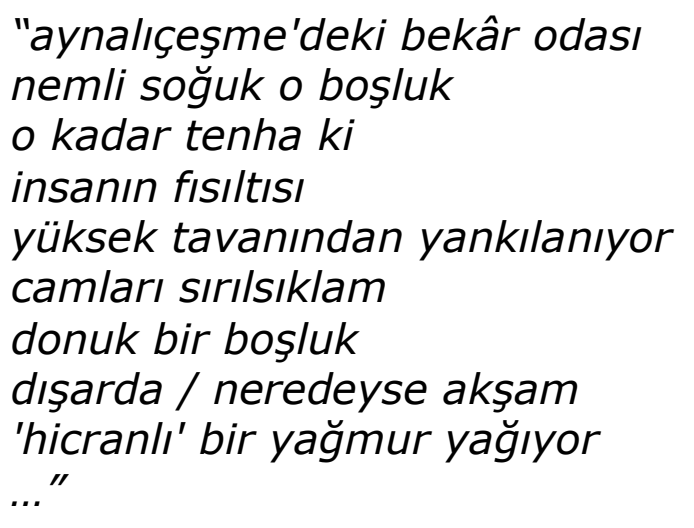

(VII. Mustafa Suphi'nin Neferi, Kimi Sevsem Sensin, 80)

Bu mekânlar, herkesin ya da mutlu ailelerin neşe içinde kaldıkları yerler değil, bazılarının kaldıkları yerlerdir. Kentte yaşayan herkes bir eve gidebilir ancak evsizler ve yabancılar otellerde kalırlar. Otel "sadece yabancıların değil, modernizmin ev'lendiremediği ya da evsiz bıraktığı 'şehirli yabancı'nın da mekânıdır. Bu yanıyla 'yurtsuz'ların yurdudur." (Narlı, 2014: 277, 305):

"otelde bir gece, bilemedin üç gece geçirip; yeniden ev rahatıklarına, yani tutulan havluya, mutfaktaki bildik yemek buğusuna dönmek başka, otel yaşamak başka! bir başka çeşit kimseler, öğle üstleri, en uykulu yüzlerini sirkeci ve tepebaşı'ndaki otel aynalarında bırakıyor; sabah üstleri yorgun argın ve bir kaç parça gelerek, takınıp yatıyor. ceplerinde çek defterleri ve tükenmez kalemler eski mektuplar, kullanılmış sinema biletleri ve kürdanlar, kaloriferleri dinleye dinleye ısınıyor. yürek içlerinde mekânsızlığın gizli ağrısı. (...) büyük şehirlerde oteller, yabancılara yalancı ev olayım derken, farkında olmayarak, içlerinde bir yirminci yüzyıl kirini biriktiriyorlar; lavabolarına her gece ve her sabah, diş macununuzun aydınlık tüten köpüğünü tükürüyor..."

\section{(1. Cinnetsaray, Bela Çiçeği, 45-59)}

Büyük kentlerde yalnızığın, evsizliğin modern zamanın bir çaresizliği ve belalı bir bunalım hali olduğu, insanın bu şekilde yaşayarak mutlu olamayacağı şiirlerdeki otel izleklerinden çıkarılabilecek sonuçlardan biridir. İnsanın bir yerde ağaçlar gibi kök salması, ağaçlara yuva yapan kuşlar gibi yaşadığı mekâna hayat kazandırması, yaşamın her gün değişen koşullarına nostaljik ve özgün değerler katması, içinde anlamlı yaşantılar kurulabilen evle ilişkilendirilmiştir. 


\section{SONUÇ}

Ev, insan zihninde sadece barınılan yer tasavvuruna sahip değildir. Ev ayrıca; aşk, aile ve akrabalık ilişkileri, anne, baba ve kardeşlerle bir arada yaşamanın ve yaşam için gerekli olan ruhsal ve bedensel gelişimin tamamını kapsayan çok derin anlamlar ve hatıralar bütünü demektir. Evin insan bilincinde yarattığı etki ve bıraktığı izler, yaşamın her alanına yayılan deneyimler dizgesi oluşturur. Denilebilir ki insanın dış dünyada ortaya koyduğu her eylem; içinde doğup büyüdüğü, yaşadığı ve yaşamakta olduğu evlerden izler taşır. Kuşkusuz bu insan eylemlerinden biri de sanat ve edebiyattır. Edebiyatta mekân kavramı olmaksızın kurgular oluşturmak ya da günlük hayatta yaşanılanları mekânlar bağlamında imgesel bir dille ortaya koymak kolaylıkla gerçekleştirilebilecek bir iş değildir. Şiir sanatında da, şairin düş ve imge dünyası, evin zengin çağrışım gücüyle şekillenmektedir. Şiirde dile getirilen her mekânın arka planında doğrudan ya da dolaylı olarak evle ilgili bir görüntü söz konusu olmaktadır.

Cumhuriyet döneminde pek çok alanda eserler ortaya koymuş olan Attila İlhan'ın şiirlerinde de, bireylerin yaşadığı mekânlar sadece ikâmet edilen yer özelliklerini sergilemez. Bu mekânlar, insanların düş dünyasını, ekonomik ve sosyal durumlarını, beklentilerini, umutlarını, hayal kırıklıklarını ve çaresizliklerini temsil edecek şekilde dile getirilmişlerdir. Şiirlere konu olan insanların ortak noktası, kendi ruh hallerini ya da yaşamsal durumlarını ortaya koyan evlerde yaşıyor olmalarıdır.

Kimi zengin köşklerde, yalılarda ya zevk ü sefa ya da kalabalıklar içinde yalnızlığı yaşarken, kimi pembe panjurlu bir evde sakin bir hayat sürmektedir. Bazı evler tehlikelerden, aramalardan saklanılan, sığınılan yerler olma özelliği sergiler. Şiirde birtakım toplumsal hassasiyetlerin ev özelinde çağrışımlar yapacak şekilde imgeleştiği evlerdir bunlar. Bazı evlerde ise kapılar hep açık, her an çıkıp gelebilecek, yalnızlığı sonlandıracak bir insan beklenmektedir. Kır hayatının hâkim olduğu yoksul köylerdeki evlerde ev halkı, birbirine kenetlenerek tabiatın güçlüklerine karşı koyabilmektedir. Bazen bulutlar ve gökyüzü bir evin çatısı olur. Yün yatakları at sırtında diyardan diyara evlerini taşıyan göçmenler şiirde yer bulur kendine. Evi olmanın, bir evle, aileyle ev'lenmiş olmanın ne kadar önemli olduğu ise şiirlerdeki bekâr odaları ve oteller özelinde dile getirilen bir konu olmuştur. Buralarda yaşayan insanlar hem kente hem de kendilerine yabancl, kimsesi olmayan, hayatta herhangi bir yerde iz bırakamamış, başkalarının izleri arasında kaybolan insanlardır.

Ev özelindeki bu yaşantılar bir araya getirildiğinde, Attila İlhan'da ev mekânı konusunda toplumsal duyarlıı̆ın ön plana çıktığı görülmektedir. 
Ev insan hayatını şekillendiren bir yer olduğu gibi; onunla gülen, onunla ağlayan, ona göre şekil ve anlam kazanan bir yerdir. Her biri birbirinden farklı şartlarda yaşayan insanların fiziki ve ruhsal durumları, yaşamlarını sürdürdükleri evlere ait imgeler kullanılarak ortaya konulmaya çalışılmıştır.

\section{KAYNAKÇA}

Alınmış, S. (2019). Türk Şiirinde Çocuk Teması 1923-1950.

(Yayımlanmamış Yüksek Lisans Tezi). Balıkesir Üniversitesi, Sosyal Bilimler Ens.

Ayten H. Koray Y. (2018). Attila İlhan'la Şiir Üstüne Konuşma. Elde Var Hüzün içinde, İstanbul: İş Bankası Kültür Yayınları, 108-114.

Bachelard, G. (1995). Ateşin Psikanalizi. (Çev.). Aytaç Yiğit. İstanbul: Bağlam Yayınları.

Bachelard, G. (1996). Mekânın Poetikası. (Çev.). A. Derman. Kesit Yayınları: İstanbul.

Canatan, K. (2018). Aile Kavramının Tanımı. Aile Sosyolojisi (7. Baskı) içinde, (Ed). K. Canatan \& E. Yıldırım, İstanbul: Açılım Kitap, 53-64. Celal M. (2019). Attila İlhan Şiirinde Bileşimler. Kimi Sevsem Sensin içinde, İstanbul: Türkiye İş Bankası Kültür Yayınları, 105-115.

Çetin, N. (2019). Şiir Çözümleme Yöntemi. Ankara: Akçağ Yayınları. Çetişli, İ. (2019). Batı Edebiyatında Edebi Akımlar. Ankara: Akçağ Yayınları.

Emiroğlu, Ö. (2019). Türkiye'de Edebiyat Toplulukları. İstanbul: Kesit Yayınları.

Ertop, K. (2005). Attila İlhan. Bütün Dünya, Başkent Üniversitesi Kültür Yayını, s. 21-24.

Geçgel, H. (2007). Bir Görüntü (imgeler) Sanatı Olarak Şiir. Erişim Adresi: http://turkoloji.cu.edu.tr/YENITURKEDEBIYATI/hulusi gecgel imgeler san at siir

Gürbilek, N. (2014). Ev Ödevi. İstanbul: Metis Yayınları.

İlhan, A. (2018a). Ayrılık Sevdaya Dâhil. İstanbul: Türkiye İş Bankası Kültür Yayınları.

İlhan, A. (2018b). Bela Çiçeği. İstanbul: Türkiye İş Bankası Kültür Yayanları.

İlhan, A. (2018c). Elde Var Hüzün. İstanbul: Türkiye İş Bankası Kültür Yayınları. 


\section{Müslüm Engin}

İlhan, A. (2018d). Yasak Sevişmek. İstanbul: Türkiye İş Bankası Kültür Yayınları.

İlhan, A. (2019a). Ben Sana Mecburum. İstanbul: Türkiye İş Bankası Kültür Yayınları.

İlhan, A. (2019b). Kimi Sevsem Sensin. İstanbul: Türkiye İş Bankası Kültür Yayınları.

İlhan, A. (2019c). Sisler Bulvarı. İstanbul: Türkiye İş Bankası Kültür Yayınları.

Keskinöz Bilen, N. (2018). İlk Ev, Dosya 41 içinde, (Ed.). Didem Kılıçkıran, Ankara: TMMOB, 84-86.

Narlı, M. (2014). Şiir ve Mekân. Ankara: Akçağ Yayınları.

Saei, M. (2019). Varlık Fenomenolojisinde Şiir ve Mekân (Yayımlanmamış Yüksek Lisans Tezi). Ankara: Hacettepe Üniversitesi, Güzel Sanatlar Enstitüsü.

Yıldırım, A. \& Şimşek, H. (2016). Sosyal Bilimlerde Nitel Araştırma Yöntemleri. Ankara: Seçkin.

Yılmaz, M. (2018). 12 Mart'ın Gölgesinde Türk Şiiri, Marksist Söylem ve Eleştirisi (1970-1980). İstanbul: Kesit Yayınları.

\section{GENİŞLETİLMİ̧̧ ÖZET}

\section{Araştırmanın Amacı}

Edebiyat eserlerindeki evlerin izlerini konu edinen bu çalışmanın amacı, Attila İlhan'ın şiirlerindeki imgeleri "ev, ev yaşamı, aile, insan ve toplum" temaları bağlamında tespit etmektir. Uzun soluklu sanat hayatı boyunca pek çok farklı döneme ve olaya şahit olmuş, pek çok farklı alanda eserler kaleme almış, şiir konusunda yeniliklere de öncülük etmiş olan Attila İlhan'ın şiirleri; Cumhuriyetin kuruluş ve mücadele felsefesi, sevgi, aşk ve toplumsal gerçeklerle idealize edilmiş zengin bir içeriğe sahiptir.

Yer (mekân) olayların geliştiği, insanların hayal ve düş dünyasının şekillendiği ve buradan da estetiğe yansıyan hareket noktasıdır. İnsanın doğup büyüdüğü ev başta olmak üzere, yaşamı süresince içinde bulunduğu bütün mekânlar düş dünyasını etkiler ve anılarda işlenmiş olan deneyimler hayata bakış açııını da etkiler. Aynı şekilde şairler de içinde bulundukları mekânın özelliklerini imgelerine yansıtırlar.

\section{Araştırmanın Soruları}

Attila İlhan şiirlerinde değişik mekân tasavvurları şiirlere ne şekilde yansımaktadır? Alt sorular ise Attila İlhan şiirlerinde değişik mekânlara örnek vermiş midir? Şiirlerdeki mekân örnekleri şairin yaşamından ya da düş dünyasından izler taşır mı? Şiirlerdeki ev mekânı aile teması ile birlikte işlenmiş midir? 
Attila İlhan şiirlerinde ev ve aile bağlamında mekânlar üzerinde bir çalışmanın literatürde yapılmamış olması bu araştırmayı bu bakımdan özgün ve yararlı kılmaktadır.

\section{Araştırmanın Yöntemi}

Bu çalışmada yöntem olarak nitel araştırma yöntemlerinden biri olan doküman analizi yöntemi kullanılmıştır. Doküman analizi yöntemi görüşme ve gözlem tekniğinin olanaklı olmadığı durumlarda, araştırmacılara belirli bir alanda yapılmış çalışmalardan yararlanarak bilgiye ulaşma olanağı sağlar. Genel olarak sosyal bilimcilerin yani tarihçiler, antropologlar, dilbilimciler, sosyolog ve psikologların bu araştırma yöntemini bir bilgi kaynağı olarak kullandığı bilinmektedir. Önceden yapılmış çalışmalar, uzun süreli bir zamana yayılmış analizler, düşük maliyetli ve zamanı tasarruflu kullanma becerisi ile örneklem çerçevesinde hareket etme kolaylığı, bu nitel analiz yöntemini araştırmacı için yararlı kılmaktadır (Yıldırım ve Şimşek, 2016: 189-192).

Bu kapsamda şairin, "Ayrılık Sevdaya Dâhil, Bela Çiçeği, Ben Sana Mecburum, Elde Var Hüzün, Kimi Sevsem Sensin, Sisler Bulvarı, Yasak Sevişmek" şiir kitapları incelenmiş ev mekânı bağlamında aile ve toplum eksenli şiirlerinden örnekler verilerek, analiz edilmişlerdir. Şairin şiirlerinde çok farklı konuların izlerinin sürülebileceği düşünüldüğünde, ev özelinde mekân sınırlamasına yönelik bir çalışmanın farklı bir bakış açısı getirmek açısından olanaklı olduğu düşünülmüştür. Çözümlemelerde Bachelard ve Narlı'nın şiir ve mekâna yönelik yaklaşımları ile Nurullah Çetin'in "Şiir Çözümleme Yöntemi" eserinden faydalanılmıştır.

\section{Sonuç ve Değerlendirme}

Evin insan bilincinde yarattığı etki ve bıraktığı izler, yaşamın her alanına yayılan deneyimler dizgisi oluşturur. Denilebilir ki insanın dış dünyada ortaya koyduğu her eylem; içinde doğup büyüdüğü, yaşadığı ve yaşamakta olduğu evlerden izler taşır. Kuşkusuz bu insan eylemlerinden biri de sanat ve edebiyattır. Edebiyatta mekân kavramı olmaksızın kurgular oluşturmak ya da bir yaşantı ile gelişigüzel dile getirilmiş imgeler ortaya koymak kolaylıkla gerçekleştirilebilecek bir iş değildir. Şiir sanatında da, şairin düş ve imge dünyası, evin zengin çağrışım gücüyle şekillenmektedir.

Attila İlhan'ın şiirlerinde de, bireylerin yaşadığı mekânlar sadece ikamet edilen yer özelliklerini sergilemez. Bu mekânlar, insanların düş dünyasını, ekonomik ve sosyal durumlarını, beklentilerini, umutlarını, hayal kırıklıklarını ve çaresizliklerini temsil edecek şekilde dile getirilmişlerdir. Şiirlere konu olan insanların ortak noktası, kendi ruh hallerini ya da yaşamsal durumlarını ortaya koyan evlerde yaşıyor olmalarıdır.

Kimi zengin köşklerde, yalılarda ya zevk ü sefa ya da kalabalıklar içinde yalnızlığı yaşarken, kimi pembe panjurlu bir evde sakin bir hayat sürmektedir. Bazı evler tehlikelerden, aramalardan saklanılan, sığınılan yerler özelliği sergiler. Şiirde birtakım toplumsal hassasiyetlerin ev özelinde çağrışımlar yapacak şekilde 
imgeleştiği evlerdir bunlar. Bazı evlerde ise kapılar hep açık, her an çıkıp gelebilecek, yalnızlığı sonlandıracak bir insan beklenmektedir. Kır hayatının hâkim olduğu yoksul köylerdeki evlerde ev halkı, birbirine kenetlenerek tabiatın güçlüklerine karşı koyabilmektedir. Bazen bulutlar ve gökyüzü bir evin çatısı olur. Yün yatakları at sırtında diyardan diyara evlerini taşıyan göçmenler şiirde yer bulur kendine. Evi olmanın, bir evle aileyle ev'lenmiş olmanın ne kadar önemli olduğu ise şiirlerdeki bekâr odaları ve oteller özelinde dile getirilen bir konu olmuştur. Buralarda yaşayan insanlar hem kente hem de kendilerine yabancı, kimsesi olmayan, hayatta herhangi bir yerde iz bırakamamış, başkalarının izleri arasında kaybolan insanlardır.

\section{EXTENDED SUMMARY}

\section{Purpose of the research}

The aim of this study, which deals with the traces of houses in literary works, is to identify the images in Attila İlhan's poems in the context of "home, home life, family, human and society" themes. The poems of Attila İlhan, who witnessed many different periods and events throughout his long-term artistic life, wrote works in many different fields, and pioneered innovations in poetry; The founding and struggle philosophy of the Republic has a rich content idealized with love, love and social realities.

The place (space) is the starting point where events develop, people's imagination and dream world are shaped, and from there it is reflected in aesthetics. All the places that a person lives in, especially the house where he was born and grew up, affect the world of dreams, and the experiences processed in the memories also affect his perspective on life. Likewise, poets reflect the characteristics of the place they are in to their images.

\section{Research Questions}

How are the different conceptions of space reflected in the poems of Attila İlhan? As for the sub-questions, did Attila İlhan give examples of different places in his poems? Do the spatial examples in the poems bear traces of the poet's life or his dream world? Is the home space in the poems treated together with the family theme?

The fact that a study on places in the context of home and family in Attila İlhan's poems has not been done in the literature makes this research unique and useful in this respect.

\section{Research Method}

In this study, document analysis method, which is one of the qualitative research methods, was used as a method. In cases where interview and observation technique is not possible, the document analysis method provides researchers with the opportunity to access information by making use of studies conducted in a specific field. In general, it is known that social scientists, namely historians, anthropologists, linguists, sociologists and psychologists, use this 
research method as a source of information. Previous studies, long-term analyzes, low-cost and time-saving skills, and ease of moving within the framework of the sample make this qualitative analysis method useful for the researcher (Yıldırım and Şimşek, 2016: 189-192).

In this context, the poet's poetry books such as "Ayrılık Sevdaya Dâhil, Bela Çiçeği, Ben Sana Mecburum, Elde Var Hüzün, Kimi Sevsem Sensin, Sisler Bulvarı, Yasak Sevişmek" were analyzed by giving examples of family and societyoriented poems in the context of home space. Considering that the traces of very different subjects can be traced in the poet's poems, it is thought that a study on the limitation of space specific to the house is possible in terms of bringing a different perspective. In the analysis, Bachelard and Narlı's approaches to poetry and space and Nurullah Çetin's "Poetry Analysis Method" were used.

\section{Results and Conclusions}

The effect and traces that the house creates on human consciousness form a string of experiences that span all areas of life. It can be said that every action of the human in the outside world; carries traces of the houses in which he was born, grew up, lived and lives in. Undoubtedly, one of these human actions is art and literature. It is not an easy task to create fictions without the concept of space in literature or to reveal images that are randomly expressed with an experience. In the art of poetry, the poet's world of dreams and images is shaped by the rich evocative power of the house.

In Attila İlhan's poems, the places where individuals live do not only exhibit the characteristics of the place of residence. These spaces are expressed in a way to represent people's dream world, their economic and social situations, their expectations, hopes, disappointments and desperation. The common point of the people who are the subject of the poems is that they live in houses that reveal their own moods or vital situations.

While some live in rich mansions and mansions either for pleasure or in solitude in crowds, some lead a quiet life in a house with pink shutters. Some houses are places where they hide from dangers and searches. These are the houses where some social sensitivities are visualized in the poem in a way that makes connotations specific to the house. In some houses, the doors are always open, a person is expected to come out at any moment and end the loneliness. In the houses in the poor villages where rural life is dominant, the households can resist the difficulties of nature by interlocking with each other. Sometimes clouds and sky become the roof of a house. Immigrants carrying their homes from land to land on horseback find a place in the poem. How important it is to have a house, to be married to a house and a family, has been a topic that has been specifically mentioned in the poems for singles rooms and hotels. The people living here are strangers to the city and to themselves, have no one, have not left a trace anywhere in life, and are lost among the traces of others. 